\title{
Chapter 3 \\ Reciprocal Regulation of Neuronal Calcium Channels by Synaptic Proteins
}

\author{
Norbert Weiss and Gerald W. Zamponi
}

\begin{abstract}
Voltage-gated $\mathrm{Ca}^{2+}$ channels represent one of the main pathways for $\mathrm{Ca}^{2+}$ entry into nerve terminals where they play a critical role in the control of synaptic exocytosis. It is traditionally believed that the vesicle-docking/release machinery must be located in the vicinity of the calcium source in order to trigger fast, efficient and spatially delimited neurotransmitter release. This tight coupling is mostly achieved by a physical interaction of the presynaptic calcium channel with several actors of the synaptic vesicle release machinery. Conversely, the binding of synaptic proteins regulates calcium channel activity, providing for fine control of presynaptic $\mathrm{Ca}^{2+}$ entry. Here, we review the current state of knowledge of the molecular mechanisms by which synaptic proteins regulates presynaptic $\mathrm{Ca}^{2+}$ channel activity.
\end{abstract}

Keywords SNARE protein - Syntaxin - SNAP-25 - Synaptotagmin • Munc18 • Rim $\bullet$ Cysteine string proteins $\bullet$ Huntingtin

\subsection{Introduction}

Voltage-gated $\mathrm{Ca}^{2+}$ channels (VGCCs) are plasma membrane proteins that convert an electrical signal into intracellular $\mathrm{Ca}^{2+}$ elevations. To date, ten genes encoding the pore-forming subunits of mammalian VGCCs have been identified. Seven genes encode the high-voltage activated (HVA) channel subfamily (comprising L-type ( $\mathrm{Ca}_{V} 1.1$ to $\left.\mathrm{Ca}_{V} 1.4\right)$, P/Q-type (Cav2.1), N-type (Cav2.2) and R-type (Cav2.3) channels) and three genes encode the low-voltage-activated (LVA) channel subfamily (composed exclusively of T-type $\left(\mathrm{Ca}_{\mathrm{V}} 3.1\right.$ to $\left.\mathrm{Ca}_{\mathrm{V}} 3.3\right)$ (Ertel et al. 2000). In addition

\footnotetext{
N. Weiss $(\bowtie) \bullet$ G.W. Zamponi

Department of Physiology and Pharmacology, Hotchkiss Brain Institute, University of Calgary,

3330 Hospital Dr. NW, Calgary, Canada T2N 4N1

e-mail: naweiss@ucalgary.ca; zamponi@ucalgary.ca
} 
to the $\mathrm{Ca}_{\mathrm{V}}$ pore-forming subunit, HVA channels are contain auxiliary subunits: $\beta$ ( $\beta_{1}$ to $\beta_{4}$, a $55 \mathrm{KDa}$ cytosolic protein of the MAGUK (membrane-associated guanylate kinase) family), $\alpha_{2} \delta\left(\alpha_{2} \delta_{1}\right.$ to $\alpha_{2} \delta_{4}$, a $170 \mathrm{KDa}$ highly glycosylated extracellular protein with a single transmembrane domain), and in some cases $\gamma\left(\gamma_{1}\right.$ to $\gamma_{8}$, a $33 \mathrm{KDa}$ transmembrane protein) (Takahashi et al. 1987). Among this wide diversity of native channels, $\mathrm{Ca}_{2} 2.1$ and $\mathrm{Ca}_{2} 2.2$ channels have been identified as the predominant $\mathrm{Ca}^{2+}$ channels involved in depolarization-evoked neurotransmitter release (Westenbroek et al. 1992, 1995, 1998; Olivera et al. 1994; Wheeler et al. 1994; Dunlap et al. 1995; Day et al. 1996; Timmermann et al. 2002). They support a transient $\mathrm{Ca}^{2+}$ microdomain of high concentration (10-50 $\left.\mu \mathrm{M}\right)$ (Schneggenburger and Neher 2005) within the active zone of the synapse that is essential for the fusion of presynaptic vesicles with the plasma membrane (Llinas et al. 1992; Edwards 2007; Neher and Sakaba 2008; Weber et al. 2010). Cav 2.1 channels support voltagedependent exocytosis in the central nervous system, whereas $\mathrm{Ca}_{\mathrm{v}} 2.2$ channels are critically involved at the peripheral synapses. In particular synapses, $\mathrm{Ca}_{\mathrm{v}} 2.3$ channels are also expressed at sufficiently high density (Day et al. 1996; Hanson and Smith 2002) to support $\mathrm{Ca}^{2+}$ entry into presysnaptic terminals (Breustedt et al. 2003; Dietrich et al. 2003) and contribute to some extent to the release of neurotransmitters (Wu et al. 1998; Gasparini et al. 2001; Kamp et al. 2005). Finally, although HVA channels support voltage-dependent exocytosis, release of neurotransmitters at rest (i.e. around the resting membrane potential of neurons) has been demonstrated in some neurons and relies on LVA Cav3.2 channels (Ivanov and Calabrese 2000; Pan et al. 2001; Egger et al. 2003; Carabelli et al. 2007; Weiss and Zamponi 2012)

In order to efficiently receive $\mathrm{Ca}^{2+}$ signals, the vesicle-docking/ release machinery must be located in the vicinity of the source of $\mathrm{Ca}^{2+}$. This is particularly important considering the high $\mathrm{Ca}^{2+}$ buffering capability of neurons (Foehring et al. 2009) and the consequent limited diffusion of free $\mathrm{Ca}^{2+}$. In mammalian synapses, this close localization relies on the direct interaction of the $\mathrm{Ca}^{2+}$ channels with several members of the vesicle release machinery which is essential for fast (within $200 \mu \mathrm{s}$ after the arrival of the action potential) and spatially delimited neurotransmitter release (Sabatini and Regehr 1996; Wadel et al. 2007). Conversely, binding of synaptic proteins potently regulates channel activity, providing a reciprocal control of $\mathrm{Ca}^{2+}$ entry to fine tune synaptic strength. Interested readers may also refer to the work of Atlas et al., for a discussion of other possible role of biochemical coupling of VGCCs with synaptic proteins (Atlas et al. 2001; Lerner et al. 2006; Marom et al. 2007; Hagalili et al. 2008; Atlas 2010; Cohen-Kutner et al. 2010; Marom et al. 2010; Weiss 2010).

\subsection{Basic Principles of Molecular Coupling Between Voltage-Gated $\mathrm{Ca}^{2+}$ Channels and SNARE Proteins}

SNARE proteins (soluble NSF ( $N$-ethylmaleimide-sensitive fusion protein) attachment protein receptor) comprising the Q-SNAREs syntaxin-1A/1B, SNAP25 (synaptosomal-associated protein of $25 \mathrm{kDa}$ ) and R-SNARE synaptobrevin 
(VAMP) (Fasshauer et al. 1998; Sutton et al. 1998) form the SNARE core complex that brings the vesicle and target membranes into close opposition, leading to fusion and exocytosis (Hanson et al. 1997; Otto et al. 1997). Not surprisingly, $\mathrm{Ca}_{\vee} 2.1$ and $\mathrm{Ca}_{\mathrm{V}} 2.2$ channels are presynaptically colocalized with syntaxin-1A at nerve terminals (Cohen et al. 1991; Westenbroek et al. 1992, 1995) and have been biochemically isolated in complex with SNARE proteins (Bennett et al. 1992; Yoshida et al. 1992; Leveque et al. 1994). Molecular characterization of $\mathrm{Ca}^{2+}$ channels/SNARE interaction has identified a synprint (synaptic protein interaction) locus in $\mathrm{Ca}_{\mathrm{v}} 2.1$ and $\mathrm{Ca}_{\mathrm{v}} 2.2$ located within the intracellular loop between domains II and III of the channels (Sheng et al. 1994; Rettig et al. 1996). This motif binds syntaxin-1A and SNAP-25 (but not synaptobrevin). Further biochemical mapping of the synprint site has identified two distinct microdomains separated by a flexible linker that independently binds syntaxin-1A and SNAP-25 (Rettig et al. 1996; Yokoyama et al. 2005). The functional relevance of the interaction has been shown by disruption of the $\mathrm{Ca}^{2+}$ channel/SNAREs coupling using peptides derived from the synprint domain (or by direct deletion of the synprint site) that alters synaptic transmission (Mochida et al. 1996; Rettig et al. 1997; Harkins et al. 2004; Keith et al. 2007). However, although the synprint site is unambiguously of key importance for fast and efficient neurotransmitter release, there is evidence that some other channel isoforms such as T-type channels, although devoid of the consensus synprint site, functionally contribute to presynaptic $\mathrm{Ca}^{2+}$ elevations and neurotransmitter release, suggesting the existence of other molecular coupling determinants. Indeed, we recently demonstrated that syntaxin-1A and SNAP-25 biochemically interact with $\mathrm{Ca}_{\mathrm{v}} 3.2 \mathrm{~T}$-type channels within the carboxy-terminal domain of the channel (Weiss et al. 2012; Fig. 3.1).

\subsection{Functional Interaction of Voltage-Gated $\mathrm{Ca}^{2+}$ Channels with SNARE Proteins}

SNARE proteins not only bring presynaptic vesicles close to the $\mathrm{Ca}^{2+}$ source but also potently modulate channel gating to fine tune presynaptic $\mathrm{Ca}^{2+}$ entries and synaptic transmission (Fig. 3.2).

\subsubsection{Syntaxin-1A}

The notion that SNARE proteins modulate $\mathrm{Ca}^{2+}$ influx through VGCC arose from electrophysiological recordings in heterologous expression systems showing that coexpression of syntaxin- $1 \mathrm{~A}$ potently modulates $\mathrm{Ca}_{\mathrm{V}} 2.1$ and $\mathrm{Ca}_{\mathrm{v}} 2.2$ gating by shifting the voltage-dependence of inactivation toward more negative membrane potentials (Bezprozvanny et al. 1995; Wiser et al. 1996; Zhong et al. 1999; Degtiar et al. 2000), thus silencing the channels and reducing presynaptic $\mathrm{Ca}^{2+}$ entry influx. This regulation was later confirmed in chick ciliary ganglion neurons and 
a
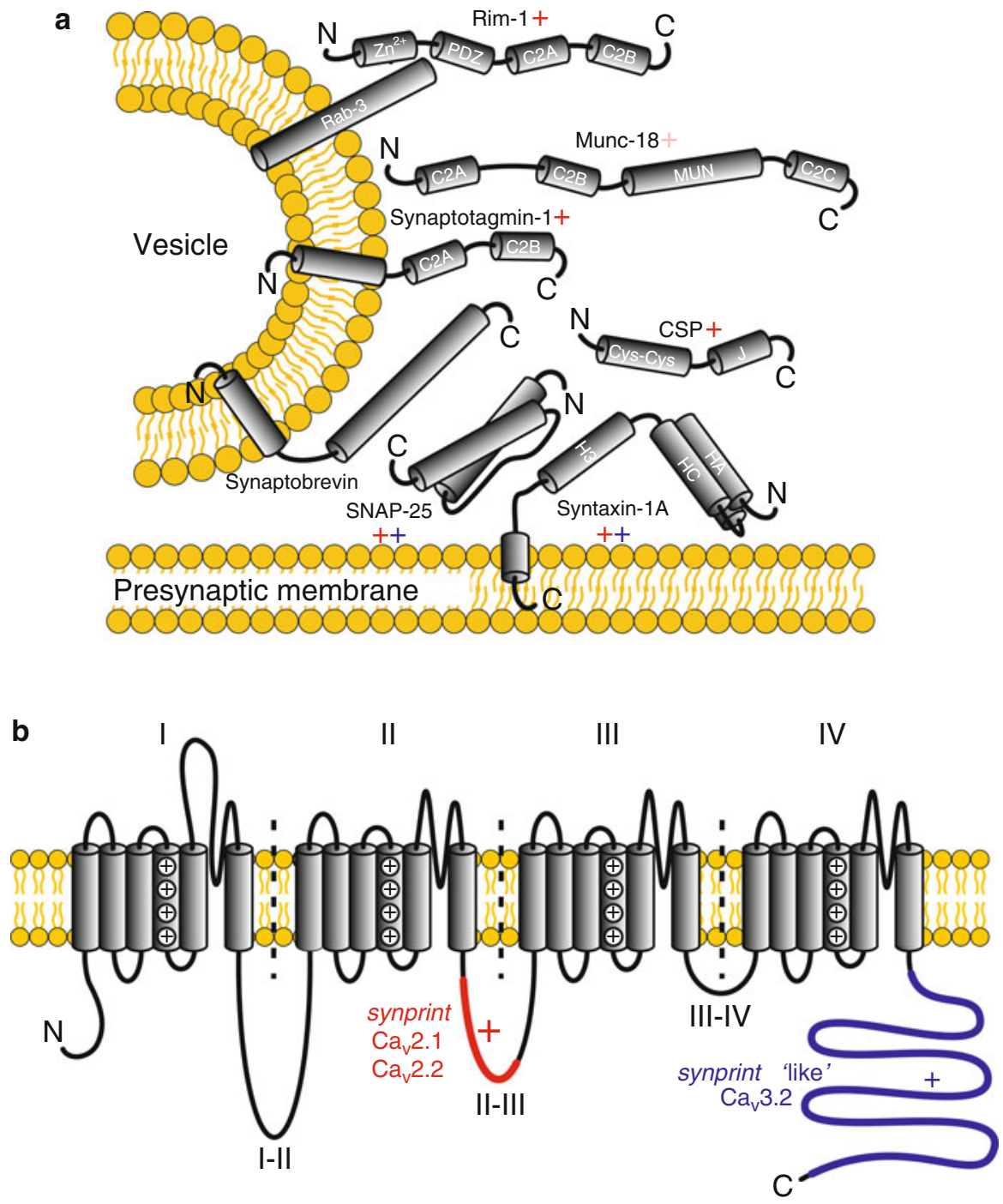

Fig. 3.1 Biochemical interactions between presynaptic $\mathrm{Ca}^{2+}$ channels and synaptic proteins. (a) Schematic representation of key synaptic proteins involved in the regulation of presynaptic $\mathrm{Ca}^{2+}$ channels. (b) Putative membrane topology of voltage-gated $\mathrm{Ca}^{2+}$ channels. The synprint domain found in $\mathrm{Ca}_{v} 2.1$ and $\mathrm{Ca}_{V} 2.2$ channels (located within the intracellular loop between domains II and III of the channel) is shown in red. In contrast, the synprint "like" domain found in $\mathrm{Ca}_{\mathrm{v}} 3.2$ T-type located within the carboxy-terminal of the channel is shown in blue. The red plus "+" signs indicate proteins that interact directly with the synprint site, whereas the blue plus signs indicate those interacting with the synprint "like" domain of $\mathrm{Ca}_{\mathrm{V}} 3.2$ T-type channels. Binding of Munc-18 with $\mathrm{Ca}_{\mathrm{V}} 2.2$ channels has been shown, but the involvement of the synprint domain requires further investigations (Adapted from (Davies and Zamponi 2008; Abbreviations: Rim-1 Rab-3 interacting molecule-1, CSP Cysteine String Proteins) 


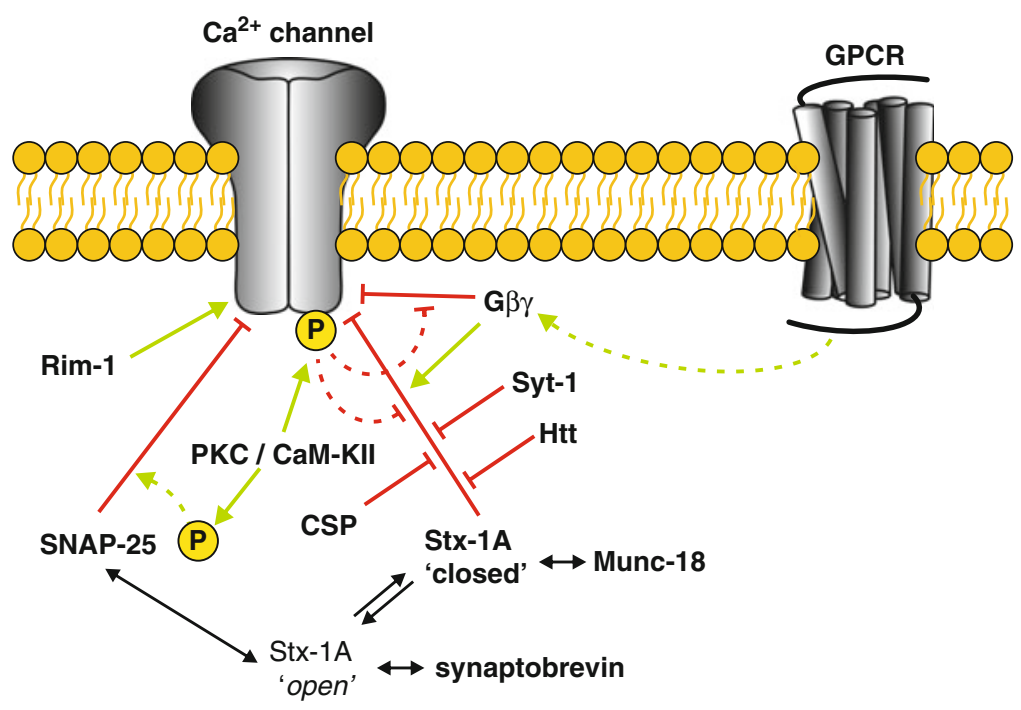

Fig. 3.2 Functional interactions between presynaptic $\mathrm{Ca}^{2+}$ channels, synaptic proteins and second messengers. The SNARE syntaxin-1A and SNAP-25, as well as release of free Gprotein $\beta \gamma$ dimer upon GPCR activation inhibit channel activity. In contrast, synaptotagmin-1, CSP and huntingtin prevent syntaxin-1A-dependent inhibition of the channel. Similarly, channel phosphorylation by PKC or CaM-KII prevents syntaxin-1A and G $\beta \gamma$-dependent inhibition, while phosphorylation of SNAP-25 promotes its inhibitory effect. Rim-1 directly potentiates $\mathrm{Ca}^{2+}$ influx (Abbreviations: StxlA syntaxin-1A, Syt-1 synaptotagmin-1, Rim-1 Rab-3 interacting molecule-1, CSP Cysteine String Proteins, Htt huntingtin, PKC protein kinase C, CaM-KII $\mathrm{Ca}^{2+} /$ calmodulindependent protein kinase II, GPCR G-protein coupled receptor. Arrows in red indicate an inhibitory regulation whereas arrows in green indicate a potentiation)

isolated mammalian nerve terminals (synaptosomes) upon application of botulinium neurotoxin $\mathrm{C} 1$ (BoNT/C1 which cleaves syntaxin-1A from its membrane anchoring domain). BoNT/C1 treatment shifted the voltage-dependence of inactivation of the channel toward depolarized potentials (Bergsman and Tsien 2000; Stanley 2003). Structure/function studies have identified the transmembrane domain of syntaxin1A, in particularly the two cysteines (C271 and C272) (Trus et al. 2001), as well as a short stretch within the H3 helical cytoplasmic domain, as fundamental for channel modulation without a direct implication in biochemical interaction with the synprint domain (Bezprozvanny et al. 2000; Jarvis et al. 2002). More recently, it was also shown that besides binding the synprint site of $\mathrm{Ca}_{\mathrm{v}} 2.2$ channels, the ten amino-terminal residues of syntaxin-1A might support inhibition of the channel (Davies et al. 2011). Although the exact molecular mechanism of syntaxin-1A mediated regulation of $\mathrm{Ca}^{2+}$ channels remains unclear, these results highlight the existence of two kinds of interaction of syntaxin-1A with the channel: (i) a biochemical interaction via the synprint domain and (ii) a functional interaction most likely involving additional yet unidentified channel determinants. Consistent with this idea, T-type $\mathrm{Ca}^{2+}$ channels that biochemically couple to syntaxin-1A 
via different channel binding determinants than the consensus synprint domain, are subject to similar syntaxin-1A-dependent modulation as $\mathrm{Ca}_{\mathrm{v}} 2.1$ and $\mathrm{Ca}_{\mathrm{v}} 2.2$ channels. Similarly, for $\mathrm{Ca}_{\mathrm{V}} 2.3$ channels, despite being devoid of the consensus synprint domain, various studies indicate that a similar syntaxin-1A-dependent regulation must occur (Bergsman and Tsien 2000; Wiser et al. 2002; Cohen and Atlas 2004). These observations suggest that gating modulation of VGCCs by syntaxin-1A likely involves modulatory channel determinants distinct from the anchoring domains. Dynamic intramolecular interactions between the intracellular loops of $\mathrm{Ca}_{\mathrm{V}} 2.1$ and $\mathrm{Ca}_{\mathrm{V}} 2.2$ channels have be reported and appear to be involved in channel gating behavior (Restituito et al. 2000; Raghib et al. 2001; Geib et al. 2002; Page et al. 2004, 2010; Sandoz et al. 2004; Agler et al. 2005; Bucci et al. 2011). Hence, channel remodeling upon syntaxin-1A binding might represent a possible consensus molecular mechanism by which syntaxin-1 A modulates $\mathrm{Ca}_{\mathrm{V}} 2 . \mathrm{x}$ and $\mathrm{Ca}_{\mathrm{V}} 3.2$ channels in a similar manner despite distinct coupling molecular determinants. Interestingly, a mutation (A454T) that segregates with familial hemiplegic migraine patients located within the intracellular linker between domains I and II of $\mathrm{Ca}_{\mathrm{v}} 2.1$ channel alters both syntaxin-1A-dependent channel gating modulation and exocytosis (Serra et al. 2010), suggesting that the I-II channel loop could play an important role in mediating syntaxin-1A modulation. In addition, a conformational switch of syntaxin-1A has been reported, that depends of the molecular partners engaged in the macromolecular complex. Hence, syntaxin-1A presents a closed conformation in complex with munc18 (or in isolation) and switches to an open conformation when in complex with SNAP-25 or synaptobrevin-2 (Dulubova et al. 1999; Brunger 2001). Interestingly, whereas syntaxin-1A in its closed state potently modulates $\mathrm{Ca}_{\mathrm{V}} 2.2$ and $\mathrm{Ca}_{\mathrm{V}} 3.2$ channel activity, coexpression of an open syntaxin1A (locked open by two point mutations (Dulubova et al. 1999)) no longer alters channel gating (Jarvis et al. 2002; Weiss et al. 2012). This conformational switch of syntaxin-1A appears to be of key physiological importance since it occurs during the vesicle release cycle (Dulubova et al. 1999; Fiebig et al. 1999; Richmond et al. 2001), suggesting that syntaxin-1A may dynamically and temporally controls presynaptic $\mathrm{Ca}^{2+}$ entry during the exocytosis process.

\subsubsection{SNAP-25}

Like syntaxin-1A, SNAP-25 non-competitively binds onto the synprint domain of $\mathrm{Ca}_{\mathrm{V}} 2.1$ and $\mathrm{Ca}_{\mathrm{v}} 2.2$ channels, as well as onto the carboxy-terminal domain of $\mathrm{Ca}_{\mathrm{v}} 3.2$ channels, to produce a similar inhibitory channel gating modulation (Wiser et al. 1996; Zhong et al. 1999; Weiss et al. 2012). The functional modulation produced by SNAP-25 was recently indirectly confirmed in native systems where siRNA silencing of SNAP-25 in glutamatergic neurons produced an increase of $\mathrm{Ca}^{2+}$ currents carried by $\mathrm{Ca}_{v} 2.1$ channels due to a depolarizing shift of the voltagedependence of inactivation (Condliffe et al. 2010; Condliffe and Matteoli 2011). Interestingly, this inhibitory regulation is no longer observed when SNAP-25 is 
co-expressed with syntaxin-1A (Wiser et al. 1996; Zhong et al. 1999; Jarvis and Zamponi 2001a; Weiss et al. 2012), suggesting that association of SNAP-25 with syntaxin-1A during the vesicle release cycle relieves channel inhibition, allowing timely presynaptic $\mathrm{Ca}^{2+}$ elevation required for membrane fusion and exocytosis (Sudhof 2004). Consistent with a key physiological importance of SNAP-25, structural or expression alterations of the protein caused by genetic mutations have been associated with numerous neuropsychiatric and neurological disorders, likely because of mis-regulation of presynaptic $\mathrm{Ca}^{2+}$ channels (Corradini et al. 2009). Finally, it was reported that phosphorylation of SNAP-25 by protein kinase $\mathrm{C}$ is required for SNAP-25-dependent inhibition of VGCCs (Pozzi et al. 2008), suggesting that like syntaxin-1A, SNAP-25-dependent modulation of channel activity may involve molecular determinants other than the synprint site.

\subsection{Modulation of Presynaptic Calcium Channels by Non SNARE Proteins}

\subsubsection{Synaptotagmin-1}

Although part of the vesicular release complex, synaptotagmin-1 is not as essential as syntaxin-1A or SNAP-25 in the membrane fusion process per se (Tucker and Chapman 2002), but rather works as a $\mathrm{Ca}^{2+}$ sensor, forming the link between presynaptic $\mathrm{Ca}^{2+}$ elevation and vesicular fusion, essential for fast and synchronous neurotransmission release (DeBello et al. 1993; Geppert et al. 1994; Augustine 2001; Fernandez-Chacon et al. 2001; Nishiki and Augustine 2001; Tucker and Chapman 2002; Koh and Bellen 2003; Xu et al. 2007). Indeed, synaptotagmin1 is characterized by an amino-terminal transmembrane region anchored in the vesicle, a variable linker, and two carboxy-terminal rich negatively charged domains (C2A and $\mathrm{C} 2 \mathrm{~B}$ ), each capable of binding $\mathrm{Ca}^{2+}$. Hence, $\mathrm{Ca}^{2+}$ binding onto the $\mathrm{C} 2 \mathrm{~A}$ domain contributes to the insertion of synaptotagmin-1 into the plasma membrane, bringing vesicles docked to the plasma membrane upon $\mathrm{Ca}^{2+}$ elevation (Fernandez-Chacon et al. 2001). In contrast, the C2B domain has been reported to biochemically interact with the synprint site of $\mathrm{Ca}_{\mathrm{V}} 2.1$ and $\mathrm{Ca}_{\mathrm{V}} 2.2$ channels (Sheng et al. 1997). Although binding of synaptotagmin-1 has no major effect on channel gating, it reduces syntaxin-1A-dependent inhibition of $\mathrm{Ca}_{\mathrm{v}} 2.2$ channels, possibly by $\mathrm{Ca}^{2+}$-dependent binding competition with syntaxin-1A (Sheng et al. 1996). Hence, syntaxin-1A preferentially interacts with the channel at rest (i.e. at low $\mathrm{Ca}^{2+}$ level) thus preventing channel activity, whereas presynaptic $\mathrm{Ca}^{2+}$ elevation favors its interaction with synaptotagmin-1 and $\mathrm{Ca}^{2+}$ entry through VGCCs that is required for the final fusion process of docked vesicles. Moreover, a $\mathrm{Ca}^{2+}$-dependent synaptotagmin-1 interaction with the $\mathrm{Ca}_{v} \beta_{4 \mathrm{a}}$ auxiliary-subunit of VGCCs has been reported (Vendel et al. 2006), providing another dynamic $\mathrm{Ca}^{2+}$ channel/vesicle interaction (Weiss 2006). 


\subsubsection{Mnc-18}

As for synaptotagmin-1, Munc18 belongs to the C2-domain containing protein family, and plays a fundamental role in the assembly/disassembly of the exocytosis machinery (Gulyas-Kovacs et al. 2007; Toonen and Verhage 2007). Genetic ablation of Munc-18 in mice leads to a complete loss of synaptic transmission (Verhage et al. 2000). Although a biochemical interaction of Munc-18 with $\mathrm{Ca}_{\mathrm{V}} 2.2$ channel within the intracellular linker between domains II and III has been reported (Chan et al. 2007), its coexpression has no effect on channel gating (Gladycheva et al. 2004). Hence, Munc-18 appears to not be a direct modulator of $\mathrm{Ca}^{2+}$ channel activity but rather interferes with syntaxin-1A-dependent channel inhibition during the vesicle release cycle as previously mentioned (Dulubova et al. 1999; Brunger 2001). This occurs by stabilizing syntaxin-1A in a closed conformation (Jarvis et al. 2002), inhibiting $\mathrm{Ca}^{2+}$ channel activity and non-necessary presynaptic $\mathrm{Ca}^{2+}$ entry in the absence of docked vesicle.

\subsubsection{Rim-1}

Rim (Rab-3 interacting molecule) is also part of a family of vesicle-associated proteins whose members share $\mathrm{C} 2$ domains. By interacting with numerous components of the presynaptic active zone such as SNAP-25 or synaptotagmin-1 (Coppola et al. 2001), it forms a protein scaffold by participating in the docking and fusion of presynaptic vesicles (Wang et al. 2000; Betz et al. 2001; Coppola et al. 2001; Ohtsuka et al. 2002; Schoch et al. 2002; Kaeser et al. 2011). Essential for short- and long-term synaptic plasticity by affecting the readily releasable pool of vesicles (Castillo et al. 2002, 2002; Blundell et al. 2010; Deng et al. 2011; Han et al. 2011), Rim proteins are also essential for proper targeting of $\mathrm{Ca}^{2+}$ channels to presynaptic terminals (Han et al. 2011) and efficient neurotransmitter release (Schoch et al. 2006). Although biochemical studies using native synapstosome membrane preparations failed to demonstrate the existence of a $\mathrm{Ca}^{2+}$ channel/Rim complex (Wong and Stanley 2010), various studies report in vitro bindings of Rim with $\mathrm{Ca}^{2+}$ channel components. Indeed, direct interaction of Rim-1 with the synprint site of $\mathrm{Ca}_{\mathrm{v}} 2.2$ channels has been shown (Coppola et al. 2001). Moreover, Rim Binding Proteins directly interact with $\mathrm{Ca}_{\mathrm{V}} 2.2$ channels (and likely with $\mathrm{Ca}_{\mathrm{v}} 2.1$ channels), possibly providing a molecular link between $\mathrm{Ca}^{2+}$ channels and Rim proteins (Hibino et al. 2002). Finally, biochemical interaction of Rim-1 with $\mathrm{Ca}_{V} \beta$ subunits has been reported, slowing $\mathrm{Ca}_{V} 2.1, \mathrm{Ca}_{\mathrm{V}} 2.2$ and $\mathrm{Ca}_{\mathrm{V}} 2.3$ channel inactivation when coexpressed in heterologous systems, thereby increasing $\mathrm{Ca}^{2+}$ influx during trains of action potentials (Kiyonaka et al. 2007), and a mutation in Rim-1 (R655H) associated with an autosomal dominant cone-rod dystrophy was found to alter Rim-1-dependent modulation of Cav2.1 channels gating (Miki et al. 2007) leading to a progressive loss of photoreceptors along with retinal degeneration (Barragan et al. 2005; Michaelides et al. 2005). Altogether, these results highlight the critical role of Rim- 1 in the modulation of $\mathrm{Ca}^{2+}$ homeostasis at nerve terminals. 


\subsubsection{Cysteine String Proteins (CSP)}

Cysteine String Proteins (CSP) are vesicle-associated protein with a key chaperone role at the synapse (Chamberlain and Burgoyne 2000). It was proposed that CSP may serve as a link between $\mathrm{Ca}_{\mathrm{V}} 2.2$ channels and presynaptic vesicles (Mastrogiacomo et al. 1994). Indeed, CSP interacts with the synprint motif of $\mathrm{Ca}_{\mathrm{V}} 2.1$ (Leveque et al. 1998; Seagar et al. 1999; Magga et al. 2000) and Cav2.2 channels (Magga et al. 2000). Moreover CSP promotes presynaptic $\mathrm{Ca}^{2+}$ influx by recruiting dormant $\mathrm{Ca}^{2+}$ channels (Chen et al. 2002). Although the molecular mechanism by which CSP promotes channel activity remains unknown, considering that CSP interacts with syntaxin-1A (Nie et al. 1999; Wu et al. 1999), it is possible that binding of CSP onto syntaxin-1A prevents syntaxin-1A-dependent channel inhibition. Hence, like synaptotagmin-1, CSP may act as a molecular channel switch activity between undocked and docked vesicles release for timely control or presynaptic $\mathrm{Ca}^{2+}$ influx.

\subsubsection{Huntingtin}

Huntingtin (Htt) is well known for its implication in Huntington's disease (Ross and Tabrizi 2011) but the exact cellular function of the protein remains unclear. However, the observation that genetic ablation of Htt is lethal in mice highlights the fundamental importance of the protein (Nasir et al. 1995). Besides interacting with numerous proteins (to date at least 20 proteins involved in gene transcription, cellular transport or cell signaling has been shown to interact with Htt), Htt directly binds to the synprint domain of $\mathrm{Ca}_{\mathrm{v}} 2.2$ channels (Swayne et al. 2005). However, as synaptotagmin-1, coexpression of $\mathrm{Htt}$ with $\mathrm{Ca}_{\mathrm{V}} 2.2$ channels has no consequence on channel gating, but prevents syntaxin-1A-dependent regulation (Swayne et al. 2005), likely by displacing binding of syntaxin-1A from the channel (Swayne et al. 2006). Hence, Htt is not a direct channel modulator per se, but might represent an important actor of synaptic activity by influencing SNARE modulation. However, it remains unclear if $\mathrm{Htt}$ is permanently expressed at the synapse under normal condition, or if it is specifically targeted under particular physiopathological states.

\subsection{Modulation of Calcium Channels by Other Signaling Pathways}

\subsubsection{G-Protein Coupled Receptors}

$\mathrm{Ca}^{2+}$ entry into presynaptic terminals is also modulated by the activation of numerous G-protein-coupled receptors (GPCRs) and second messengers (Jarvis and Zamponi 2001b). Indeed, activation of specific GPCRs following the liberation of 
neurotransmitters initiates a negative feedback regulation on presynaptic VGCCs, inhibiting presynaptic $\mathrm{Ca}^{2+}$ entry thus terminating synaptic transmission (Brown and Sihra 2008). This spatially delimited regulation (Forscher et al. 1986) relies on the direct binding of free G-protein $\beta \gamma$ dimers release upon GPCR activation (Herlitze et al. 1996; Ikeda 1996) to specific intracellular regions of the channel (De Waard et al. 1997, 2005; Zamponi et al. 1997; Tedford and Zamponi 2006). Interestingly, it was shown that cleavage of syntaxin-1A by the botulinium neurotoxin $\mathrm{C} 1$ in chick calyx synapses prevents G-protein-dependent inhibition of $\mathrm{Ca}^{2+}$ currents, suggesting the involvement of syntaxin-1A in presynaptic G-protein regulation of $\mathrm{Ca}^{2+}$ channels (Stanley and Mirotznik 1997; Silinsky 2005). In vitro studies have later revealed an interaction of syntaxin-1A with G-protein $\beta \gamma$ dimers, and although syntaxin-1A is not critical for G-protein regulation it potentiates the inhibition in a receptor-independent manner (Jarvis et al. 2000; Jarvis and Zamponi 2001a; Lu et al. 2001). Moreover, G-protein $\beta \gamma$ dimers not only interact with syntaxin-1A, but also with SNAP-25 to mediate presynaptic inhibition (Gerachshenko et al. 2005). Finally, besides to modulate $\mathrm{Ca}^{2+}$ channel activity, it was shown that G-protein $\beta \gamma$ dimers and synaptotagmin-1 compete for binding to the core SNARE complex in a $\mathrm{Ca}^{2+}$-dependent manner such that at high $\mathrm{Ca}^{2+}$ concentration synaptotagmin- 1 can displace $\mathrm{G} \beta \gamma$ binding (Yoon et al. 2007). Hence, $\mathrm{Ca}^{2+}$ elevation in presynaptic terminals may prevent G-protein inhibition, likely by preventing binding of G $\beta \gamma$ with SNARE proteins (Yoon et al. 2007). To add further complexity, it was recently reported that Rim-1 promotes relief of G-protein inhibition of $\mathrm{Ca}_{\mathrm{v}} 2.2$ channels by modulating channel inactivation (Weiss et al. 2011). Altogether, these results highlight the extreme interplay between GPCRdependent regulation and the molecular actors of the exocytosis process to fine tune presynaptic $\mathrm{Ca}^{2+}$ entry.

\subsubsection{Phosphorylation}

In vitro studies have shown that the protein kinase $\mathrm{C}(\mathrm{PKC})$, as well as the $\mathrm{Ca}^{2+}$-calmodulin-dependent kinase II (CaM-KII) are able to phosphorylate the synprint domain of $\mathrm{Ca}_{\mathrm{V}} 2.2$ channels (Yokoyama et al. 1997, 2005), preventing binding of syntaxin-1A and SNAP-25 (Yokoyama et al. 1997) and thus preventing SNARE-dependent inhibition of the channel (Jarvis and Zamponi 2001a). However, uncoupling of SNARE proteins from the channel upon synprint phosphorylation, most likely represent a termination signal for synaptic exocytosis. It was reported that phosphorylation of the synprint site of $\mathrm{Cav}_{\mathrm{V}} 2.1$ channels by the glycogen synthase kinase-3 (GSK-3) prevents SNARE interaction with the channel but also inhibits synaptic exocytosis possibly by interfering with $\mathrm{Ca}^{2+}$ channel/SNARE coupling (Zhu et al. 2010). Interestingly, phosphorylation of syntaxin-1A and SNAP-25 by PKC or CaM-KII does not alter interaction with the synprint site (Yokoyama et al. 1997), Hence, PKC- and CaM-KII-dependent phosphorylation of 
the synprint site may serve as a biochemical switch for interaction/modulation of voltage-gated $\mathrm{Ca}^{2+}$ channels with SNARE protein complexes.

\subsection{Concluding Remarks}

Like most key cellular functions, control of neurotransmitter release by presynaptic $\mathrm{Ca}^{2+}$ channels is highly regulated. The various components of the exocytosis machinery, besides localizing the vesicles within the vicinity of the source of $\mathrm{Ca}^{2+}$, provide a potent reciprocal control of presynaptic $\mathrm{Ca}^{2+}$ influx by modulating channel gating. This dynamic regulation appears to be fundamental to dynamically and temporally fine tune neurotransmitter release. Surprisingly, as highlighted in this chapter, the regulation of presynaptic $\mathrm{Ca}^{2+}$ channels appears extremely complex, with intricate interplay between different types of synaptic proteins and second messenger signaling pathways, but also highly redundant. This important redundancy in $\mathrm{Ca}^{2+}$ channel regulation by various presynaptic proteins might ensure a security control over a fundamental physiological function. Finally, although $\mathrm{Ca}_{\mathrm{v}} 2.1 / \mathrm{Ca}_{\mathrm{v}} 2.2$ and $\mathrm{Ca}_{\mathrm{V}} 3.2 \mathrm{~T}$-type channels use completely distinct channel molecular determinants to interact with the vesicular machinery, they are functionally regulated by syntaxin$1 \mathrm{~A}$ and SNAP-25 in a strikingly similar manner. This may perhaps underscore the fundamental importance of localizing the exocytosis machinery near the source of $\mathrm{Ca}^{2+}$, and providing tight control over $\mathrm{Ca}^{2+}$ entry.

Acknowledgements Norbert Weiss is supported by fellowships from Alberta Innovates-Health Solutions (AI-HS) and from Hotchkiss Brain Institute. Gerald W. Zamponi is funded by the Canadian Institutes of Health Research, is a Canada Research Chair and AI-HS Scientist.

\section{References}

Agler HL, Evans J, Tay LH, Anderson MJ, Colecraft HM, Yue DT (2005) G protein-gated inhibitory module of N-type ( $\left.\mathrm{Ca}_{\mathrm{V}} 2.2\right) \mathrm{Ca}^{2+}$ channels. Neuron 46:891-904

Atlas D (2010) Signaling role of the voltage-gated calcium channel as the molecular on/off-switch of secretion. Cell Signal 22:1597-1603

Atlas D, Wiser O, Trus M (2001) The voltage-gated $\mathrm{Ca}^{2+}$ channel is the $\mathrm{Ca}^{2+}$ sensor of fast neurotransmitter release. Cell Mol Neurobiol 21:717-731

Augustine GJ (2001) How does calcium trigger neurotransmitter release? Curr Opin Neurobiol 11:320-326

Barragan I, Marcos I, Borrego S, Antinolo G (2005) Molecular analysis of RIM1 in autosomal recessive Retinitis pigmentosa. Ophthalmic Res 37:89-93

Bennett MK, Calakos N, Scheller RH (1992) Syntaxin: a synaptic protein implicated in docking of synaptic vesicles at presynaptic active zones. Science 257:255-259

Bergsman JB, Tsien RW (2000) Syntaxin modulation of calcium channels in cortical synaptosomes as revealed by botulinum toxin C1. J Neurosci 20:4368-4378

Betz A, Thakur P, Junge HJ, Ashery U, Rhee JS, Scheuss V et al (2001) Functional interaction of the active zone proteins Munc13-1 and RIM1 in synaptic vesicle priming. Neuron 30:183-196 
Bezprozvanny I, Scheller RH, Tsien RW (1995) Functional impact of syntaxin on gating of N-type and Q-type calcium channels. Nature 378:623-626

Bezprozvanny I, Zhong P, Scheller RH, Tsien RW (2000) Molecular determinants of the functional interaction between syntaxin and $\mathrm{N}$-type $\mathrm{Ca}^{2+}$ channel gating. Proc Natl Acad Sci U S A 97:13943-13948

Blundell J, Kaeser PS, Sudhof TC, Powell CM (2010) RIM1alpha and interacting proteins involved in presynaptic plasticity mediate prepulse inhibition and additional behaviors linked to schizophrenia. J Neurosci 30:5326-5333

Breustedt J, Vogt KE, Miller RJ, Nicoll RA, Schmitz D (2003) Alpha1E-containing $\mathrm{Ca}^{2+}$ channels are involved in synaptic plasticity. Proc Natl Acad Sci U S A 100:12450-12455

Brown DA, Sihra TS (2008) Presynaptic signaling by heterotrimeric G-proteins. Handb Exp Pharmacol 184:207-260

Brunger AT (2001) Structure of proteins involved in synaptic vesicle fusion in neurons. Annu Rev Biophys Biomol Struct 30:157-171

Bucci G, Mochida S, Stephens GJ (2011) Inhibition of synaptic transmission and G protein modulation by synthetic $\mathrm{Ca}_{\mathrm{v}} 2.2 \mathrm{Ca}^{2+}$ channel peptides. J Physiol 589:3085-3101

Carabelli V, Marcantoni A, Comunanza V, de Luca A, Diaz J, Borges R et al (2007) Chronic hypoxia up-regulates alpha1H T-type channels and low-threshold catecholamine secretion in rat chromaffin cells. J Physiol 584:149-165

Castillo PE, Schoch S, Schmitz F, Sudhof TC, Malenka RC (2002) RIM1alpha is required for presynaptic long-term potentiation. Nature 415:327-330

Chamberlain LH, Burgoyne RD (2000) Cysteine-string protein: the chaperone at the synapse. J Neurochem 74:1781-1789

Chan AW, Khanna R, Li Q, Stanley EF (2007) Munc18: a presynaptic transmitter release site N type $\left(\mathrm{Ca}_{\mathrm{V}} 2.2\right)$ calcium channel interacting protein. Channels (Austin) 1:11-20

Chen S, Zheng X, Schulze KL, Morris T, Bellen H, Stanley EF (2002) Enhancement of presynaptic calcium current by cysteine string protein. J Physiol 538:383-389

Cohen R, Atlas D (2004) R-type voltage-gated $\mathrm{Ca}^{2+}$ channel interacts with synaptic proteins and recruits synaptotagmin to the plasma membrane of Xenopus oocytes. Neuroscience 128: 831-841

Cohen MW, Jones OT, Angelides KJ (1991) Distribution of $\mathrm{Ca}^{2+}$ channels on frog motor nerve terminals revealed by fluorescent omega-conotoxin. J Neurosci 11:1032-1039

Cohen-Kutner M, Nachmanni D, Atlas D (2010) Ca 2.1 (P/Q channel) interaction with synaptic proteins is essential for depolarization-evoked release. Channels (Austin) 4:266-277

Condliffe SB, Matteoli M (2011) Inactivation kinetics of voltage-gated calcium channels in glutamatergic neurons are influenced by SNAP-25. Channels (Austin) 5:304-307

Condliffe SB, Corradini I, Pozzi D, Verderio C, Matteoli M (2010) Endogenous SNAP-25 regulates native voltage-gated calcium channels in glutamatergic neurons. J Biol Chem 285:2496824976

Coppola T, Magnin-Luthi S, Perret-Menoud V, Gattesco S, Schiavo G, Regazzi R (2001) Direct interaction of the Rab3 effector RIM with $\mathrm{Ca}^{2+}$ channels, SNAP-25, and synaptotagmin. J Biol Chem 276:32756-32762

Corradini I, Verderio C, Sala M, Wilson MC, Matteoli M (2009) SNAP-25 in neuropsychiatric disorders. Ann N Y Acad Sci 1152:93-99

Davies JN, Zamponi GW (2008) Old proteins, developing roles: the regulation of calcium channels by synaptic proteins. Channels (Austin) 2:130-138

Davies JN, Jarvis SE, Zamponi GW (2011) Bipartite syntaxin 1A interactions mediate $\mathrm{Ca}_{\mathrm{V}} 2.2$ calcium channel regulation. Biochem Biophys Res Commun 411:562-568

Day NC, Shaw PJ, McCormack AL, Craig PJ, Smith W, Beattie R et al (1996) Distribution of alpha 1A, alpha 1B and alpha 1E voltage-dependent calcium channel subunits in the human hippocampus and parahippocampal gyrus. Neuroscience 71:1013-1024

De Waard M, Liu H, Walker D, Scott VE, Gurnett CA, Campbell KP (1997) Direct binding of G-protein betagamma complex to voltage-dependent calcium channels. Nature 385:446-450 
De Waard M, Hering J, Weiss N, Feltz A (2005) How do G proteins directly control neuronal $\mathrm{Ca}^{2+}$ channel function? Trends Pharmacol Sci 26:427-436

DeBello WM, Betz H, Augustine GJ (1993) Synaptotagmin and neurotransmitter release. Cell 74:947-950

Degtiar VE, Scheller RH, Tsien RW (2000) Syntaxin modulation of slow inactivation of N-type calcium channels. J Neurosci 20:4355-4367

Deng L, Kaeser PS, Xu W, Sudhof TC (2011) RIM proteins activate vesicle priming by reversing autoinhibitory homodimerization of Munc13. Neuron 69:317-331

Dietrich D, Kirschstein T, Kukley M, Pereverzev A, von der Brelie C, Schneider T et al (2003) Functional specialization of presynaptic $\mathrm{Ca}_{\mathrm{v}} 2.3 \mathrm{Ca}^{2+}$ channels. Neuron 39:483-496

Dulubova I, Sugita S, Hill S, Hosaka M, Fernandez I, Sudhof TC et al (1999) A conformational switch in syntaxin during exocytosis: role of munc18. Embo J 18:4372-4382

Dunlap K, Luebke JI, Turner TJ (1995) Exocytotic $\mathrm{Ca}^{2+}$ channels in mammalian central neurons. Trends Neurosci 18:89-98

Edwards RH (2007) The neurotransmitter cycle and quantal size. Neuron 55:835-858

Egger V, Svoboda K, Mainen ZF (2003) Mechanisms of lateral inhibition in the olfactory bulb: efficiency and modulation of spike-evoked calcium influx into granule cells. J Neurosci 23:7551-7558

Ertel EA, Campbell KP, Harpold MM, Hofmann F, Mori Y, Perez-Reyes E et al (2000) Nomenclature of voltage-gated calcium channels. Neuron 25:533-535

Fasshauer D, Sutton RB, Brunger AT, Jahn R (1998) Conserved structural features of the synaptic fusion complex: SNARE proteins reclassified as Q- and R-SNAREs. Proc Natl Acad Sci U S A 95:15781-15786

Fernandez-Chacon R, Konigstorfer A, Gerber SH, Garcia J, Matos MF, Stevens CF et al (2001) Synaptotagmin I functions as a calcium regulator of release probability. Nature 410:41-49

Fiebig KM, Rice LM, Pollock E, Brunger AT (1999) Folding intermediates of SNARE complex assembly. Nat Struct Biol 6:117-123

Foehring RC, Zhang XF, Lee JC, Callaway JC (2009) Endogenous calcium buffering capacity of substantia nigral dopamine neurons. J Neurophysiol 102:2326-2333

Forscher P, Oxford GS, Schulz D (1986) Noradrenaline modulates calcium channels in avian dorsal root ganglion cells through tight receptor-channel coupling. J Physiol 379:131-144

Gasparini S, Kasyanov AM, Pietrobon D, Voronin LL, Cherubini E (2001) Presynaptic R-type calcium channels contribute to fast excitatory synaptic transmission in the rat hippocampus. J Neurosci 21:8715-8721

Geib S, Sandoz G, Cornet V, Mabrouk K, Fund-Saunier O, Bichet D et al (2002) The interaction between the I-II loop and the III-IV loop of $\mathrm{Ca}_{\mathrm{V}} 2.1$ contributes to voltage-dependent inactivation in a beta -dependent manner. J Biol Chem 277:10003-10013

Geppert M, Goda Y, Hammer RE, Li C, Rosahl TW, Stevens CF et al (1994) Synaptotagmin I: a major $\mathrm{Ca}^{2+}$ sensor for transmitter release at a central synapse. Cell 79:717-727

Gerachshenko T, Blackmer T, Yoon EJ, Bartleson C, Hamm HE, Alford S (2005) Gbetagamma acts at the C terminus of SNAP-25 to mediate presynaptic inhibition. Nat Neurosci 8:597-605

Gladycheva SE, Ho CS, Lee YY, Stuenkel EL (2004) Regulation of syntaxin1A-munc18 complex for SNARE pairing in HEK293 cells. J Physiol 558:857-871

Gulyas-Kovacs A, de Wit H, Milosevic I, Kochubey O, Toonen R, Klingauf J et al (2007) Munc181: sequential interactions with the fusion machinery stimulate vesicle docking and priming. J Neurosci 27:8676-8686

Hagalili Y, Bachnoff N, Atlas D (2008) The voltage-gated $\mathrm{Ca}^{2+}$ channel is the $\mathrm{Ca}^{2+}$ sensor protein of secretion. Biochemistry 47:13822-13830

Han Y, Kaeser PS, Sudhof TC, Schneggenburger R (2011) RIM determines $\mathrm{Ca}^{2+}$ channel density and vesicle docking at the presynaptic active zone. Neuron 69:304-316

Hanson JE, Smith Y (2002) Subcellular distribution of high-voltage-activated calcium channel subtypes in rat globus pallidus neurons. J Comp Neurol 442:89-98

Hanson PI, Heuser JE, Jahn R (1997) Neurotransmitter release-four years of SNARE complexes. Curr Opin Neurobiol 7:310-315 
Harkins AB, Cahill AL, Powers JF, Tischler AS, Fox AP (2004) Deletion of the synaptic protein interaction site of the N-type $\left(\mathrm{Ca}_{\mathrm{V}} 2.2\right)$ calcium channel inhibits secretion in mouse pheochromocytoma cells. Proc Natl Acad Sci U S A 101:15219-15224

Herlitze S, Garcia DE, Mackie K, Hille B, Scheuer T, Catterall WA (1996) Modulation of $\mathrm{Ca}^{2+}$ channels by G-protein beta gamma subunits. Nature 380:258-262

Hibino H, Pironkova R, Onwumere O, Vologodskaia M, Hudspeth AJ, Lesage F (2002) RIM binding proteins (RBPs) couple Rab3-interacting molecules (RIMs) to voltage-gated $\mathrm{Ca}^{2+}$ channels. Neuron 34:411-423

Ikeda SR (1996) Voltage-dependent modulation of N-type calcium channels by G-protein beta gamma subunits. Nature 380:255-258

Ivanov AI, Calabrese RL (2000) Intracellular $\mathrm{Ca}^{2+}$ dynamics during spontaneous and evoked activity of leech heart interneurons: low-threshold Ca currents and graded synaptic transmission. J Neurosci 20:4930-4943

Jarvis SE, Zamponi GW (2001a) Distinct molecular determinants govern syntaxin 1A-mediated inactivation and G-protein inhibition of N-type calcium channels. J Neurosci 21:2939-2948

Jarvis SE, Zamponi GW (2001b) Interactions between presynaptic $\mathrm{Ca}^{2+}$ channels, cytoplasmic messengers and proteins of the synaptic vesicle release complex. Trends Pharmacol Sci 22: $519-525$

Jarvis SE, Magga JM, Beedle AM, Braun JE, Zamponi GW (2000) G protein modulation of N-type calcium channels is facilitated by physical interactions between syntaxin $1 \mathrm{~A}$ and Gbetagamma. J Biol Chem 275:6388-6394

Jarvis SE, Barr W, Feng ZP, Hamid J, Zamponi GW (2002) Molecular determinants of syntaxin 1 modulation of N-type calcium channels. J Biol Chem 277:44399-44407

Kaeser PS, Deng L, Wang Y, Dulubova I, Liu X, Rizo J et al (2011) RIM proteins tether $\mathrm{Ca}^{2+}$ channels to presynaptic active zones via a direct PDZ-domain interaction. Cell 144:282-295

Kamp MA, Krieger A, Henry M, Hescheler J, Weiergraber M, Schneider T (2005) Presynaptic 'Cav2.3-containing' E-type Ca channels share dual roles during neurotransmitter release. Eur J Neurosci 21:1617-1625

Keith RK, Poage RE, Yokoyama CT, Catterall WA, Meriney SD (2007) Bidirectional modulation of transmitter release by calcium channel/syntaxin interactions in vivo. J Neurosci 27:265-269

Kiyonaka S, Wakamori M, Miki T, Uriu Y, Nonaka M, Bito H et al (2007) RIM1 confers sustained activity and neurotransmitter vesicle anchoring to presynaptic $\mathrm{Ca}^{2+}$ channels. Nat Neurosci 10:691-701

Koh TW, Bellen HJ (2003) Synaptotagmin I, a $\mathrm{Ca}^{2+}$ sensor for neurotransmitter release. Trends Neurosci 26:413-422

Lerner I, Trus M, Cohen R, Yizhar O, Nussinovitch I, Atlas D (2006) Ion interaction at the pore of Lc-type $\mathrm{Ca}^{2+}$ channel is sufficient to mediate depolarization-induced exocytosis. J Neurochem 97:116-127

Leveque C, el Far O, Martin-Moutot N, Sato K, Kato R, Takahashi M et al (1994) Purification of the $\mathrm{N}$-type calcium channel associated with syntaxin and synaptotagmin. A complex implicated in synaptic vesicle exocytosis. J Biol Chem 269:6306-6312

Leveque C, Pupier S, Marqueze B, Geslin L, Kataoka M, Takahashi M et al (1998) Interaction of cysteine string proteins with the alpha1 A subunit of the P/Q-type calcium channel. J Biol Chem 273:13488-13492

Llinas R, Sugimori M, Silver RB (1992) Microdomains of high calcium concentration in a presynaptic terminal. Science 256:677-679

Lu Q, AtKisson MS, Jarvis SE, Feng ZP, Zamponi GW, Dunlap K (2001) Syntaxin 1A supports voltage-dependent inhibition of alpha1B $\mathrm{Ca}^{2+}$ channels by Gbetagamma in chick sensory neurons. J Neurosci 21:2949-2957

Magga JM, Jarvis SE, Arnot MI, Zamponi GW, Braun JE (2000) Cysteine string protein regulates $\mathrm{G}$ protein modulation of N-type calcium channels. Neuron 28:195-204

Marom M, Sebag A, Atlas D (2007) Cations residing at the selectivity filter of the voltage-gated $\mathrm{Ca}^{2+}$-channel modify fusion-pore kinetics. Channels (Austin) 1:377-386 
Marom M, Hagalili Y, Sebag A, Tzvier L, Atlas D (2010) Conformational changes induced in voltage-gated calcium channel $\mathrm{Ca}_{V} 1.2$ by BayK 8644 or FPL64176 modify the kinetics of secretion independently of $\mathrm{Ca}^{2+}$ influx. J Biol Chem 285:6996-7005

Mastrogiacomo A, Parsons SM, Zampighi GA, Jenden DJ, Umbach JA, Gundersen CB (1994) Cysteine string proteins: a potential link between synaptic vesicles and presynaptic $\mathrm{Ca}^{2+}$ channels. Science 263:981-982

Michaelides M, Holder GE, Hunt DM, Fitzke FW, Bird AC, Moore AT (2005) A detailed study of the phenotype of an autosomal dominant cone-rod dystrophy (CORD7) associated with mutation in the gene for RIM1. Br J Ophthalmol 89:198-206

Miki T, Kiyonaka S, Uriu Y, De Waard M, Wakamori M, Beedle AM et al (2007) Mutation associated with an autosomal dominant cone-rod dystrophy CORD7 modifies RIM1-mediated modulation of voltage-dependent $\mathrm{Ca}^{2+}$ channels. Channels (Austin) 1:144-147

Mochida S, Sheng ZH, Baker C, Kobayashi H, Catterall WA (1996) Inhibition of neurotransmission by peptides containing the synaptic protein interaction site of $\mathrm{N}$-type $\mathrm{Ca}^{2+}$ channels. Neuron 17:781-788

Nasir J, Floresco SB, O’Kusky JR, Diewert VM, Richman JM, Zeisler J et al (1995) Targeted disruption of the Huntington's disease gene results in embryonic lethality and behavioral and morphological changes in heterozygotes. Cell 81:811-823

Neher E, Sakaba T (2008) Multiple roles of calcium ions in the regulation of neurotransmitter release. Neuron 59:861-872

Nie Z, Ranjan R, Wenniger JJ, Hong SN, Bronk P, Zinsmaier KE (1999) Overexpression of cysteine-string proteins in Drosophila reveals interactions with syntaxin. J Neurosci 19:1027010279

Nishiki TI, Augustine GJ (2001) Calcium-dependent neurotransmitter release: synaptotagmin to the rescue. J Comp Neurol 436:1-3

Ohtsuka T, Takao-Rikitsu E, Inoue E, Inoue M, Takeuchi M, Matsubara K et al (2002) Cast: a novel protein of the cytomatrix at the active zone of synapses that forms a ternary complex with RIM1 and munc13-1. J Cell Biol 158:577-590

Olivera BM, Miljanich GP, Ramachandran J, Adams ME (1994) Calcium channel diversity and neurotransmitter release: the omega-conotoxins and omega-agatoxins. Annu Rev Biochem 63:823-867

Otto H, Hanson PI, Jahn R (1997) Assembly and disassembly of a ternary complex of synaptobrevin, syntaxin, and SNAP-25 in the membrane of synaptic vesicles. Proc Natl Acad Sci U S A 94:6197-6201

Page KM, Heblich F, Davies A, Butcher AJ, Leroy J, Bertaso F et al (2004) Dominant-negative calcium channel suppression by truncated constructs involves a kinase implicated in the unfolded protein response. J Neurosci 24:5400-5409

Page KM, Heblich F, Margas W, Pratt WS, Nieto-Rostro M, Chaggar K et al (2010) N terminus is key to the dominant negative suppression of $\mathrm{Ca}_{\mathrm{v}} 2$ calcium channels: implications for episodic ataxia type 2. J Biol Chem 285:835-844

Pan ZH, Hu HJ, Perring P, Andrade R (2001) T-type $\mathrm{Ca}^{2+}$ channels mediate neurotransmitter release in retinal bipolar cells. Neuron 32:89-98

Pozzi D, Condliffe S, Bozzi Y, Chikhladze M, Grumelli C, Proux-Gillardeaux V et al (2008) Activity-dependent phosphorylation of Ser187 is required for SNAP-25-negative modulation of neuronal voltage-gated calcium channels. Proc Natl Acad Sci U S A 105:323-328

Raghib A, Bertaso F, Davies A, Page KM, Meir A, Bogdanov Y et al (2001) Dominantnegative synthesis suppression of voltage-gated calcium channel $\mathrm{Ca}_{\mathrm{V}} 2.2$ induced by truncated constructs. J Neurosci 21:8495-8504

Restituito S, Cens T, Barrere C, Geib S, Galas S, De Waard M et al (2000) The $\beta 2$ a subunit is a molecular groom for the $\mathrm{Ca}^{2+}$ channel inactivation gate. J Neurosci 20:9046-9052

Rettig J, Sheng ZH, Kim DK, Hodson CD, Snutch TP, Catterall WA (1996) Isoform-specific interaction of the alpha1A subunits of brain $\mathrm{Ca}^{2+}$ channels with the presynaptic proteins syntaxin and SNAP-25. Proc Natl Acad Sci U S A 93:7363-7368 
Rettig J, Heinemann C, Ashery U, Sheng ZH, Yokoyama CT, Catterall WA et al (1997) Alteration of $\mathrm{Ca}^{2+}$ dependence of neurotransmitter release by disruption of $\mathrm{Ca}^{2+}$ channel/syntaxin interaction. J Neurosci 17:6647-6656

Richmond JE, Weimer RM, Jorgensen EM (2001) An open form of syntaxin bypasses the requirement for UNC-13 in vesicle priming. Nature 412:338-341

Ross CA, Tabrizi SJ (2011) Huntington's disease: from molecular pathogenesis to clinical treatment. Lancet Neurol 10:83-98

Sabatini BL, Regehr WG (1996) Timing of neurotransmission at fast synapses in the mammalian brain. Nature 384:170-172

Sandoz G, Lopez-Gonzalez I, Stamboulian S, Weiss N, Arnoult C, De Waard M (2004) Repositioning of charged I-II loop amino acid residues within the electric field by beta subunit as a novel working hypothesis for the control of fast P/Q calcium channel inactivation. Eur J Neurosci 19:1759-1772

Schneggenburger R, Neher E (2005) Presynaptic calcium and control of vesicle fusion. Curr Opin Neurobiol 15:266-274

Schoch S, Castillo PE, Jo T, Mukherjee K, Geppert M, Wang Y et al (2002) RIM1alpha forms a protein scaffold for regulating neurotransmitter release at the active zone. Nature 415:321-326

Schoch S, Mittelstaedt T, Kaeser PS, Padgett D, Feldmann N, Chevaleyre V et al (2006) Redundant functions of RIM1alpha and RIM2alpha in $\mathrm{Ca}^{2+}$-triggered neurotransmitter release. Embo J 25:5852-5863

Seagar M, Leveque C, Charvin N, Marqueze B, Martin-Moutot N, Boudier JA et al (1999) Interactions between proteins implicated in exocytosis and voltage-gated calcium channels. Philos Trans R Soc Lond B Biol Sci 354:289-297

Serra SA, Cuenca-Leon E, Llobet A, Rubio-Moscardo F, Plata C, Carreno O et al (2010) A mutation in the first intracellular loop of CACNA1A prevents P/Q channel modulation by SNARE proteins and lowers exocytosis. Proc Natl Acad Sci U S A 107:1672-1677

Sheng ZH, Rettig J, Takahashi M, Catterall WA (1994) Identification of a syntaxin-binding site on N-type calcium channels. Neuron 13:1303-1313

Sheng ZH, Rettig J, Cook T, Catterall WA (1996) Calcium-dependent interaction of N-type calcium channels with the synaptic core complex. Nature 379:451-454

Sheng ZH, Yokoyama CT, Catterall WA (1997) Interaction of the synprint site of N-type $\mathrm{Ca}^{2+}$ channels with the C2B domain of synaptotagmin I. Proc Natl Acad Sci U S A 94:5405-5410

Silinsky EM (2005) Modulation of calcium currents is eliminated after cleavage of a strategic component of the mammalian secretory apparatus. J Physiol 566:681-688

Stanley EF (2003) Syntaxin I modulation of presynaptic calcium channel inactivation revealed by botulinum toxin C1. Eur J Neurosci 17:1303-1305

Stanley EF, Mirotznik RR (1997) Cleavage of syntaxin prevents G-protein regulation of presynaptic calcium channels. Nature 385:340-343

Sudhof TC (2004) The synaptic vesicle cycle. Annu Rev Neurosci 27:509-547

Sutton RB, Fasshauer D, Jahn R, Brunger AT (1998) Crystal structure of a SNARE complex involved in synaptic exocytosis at 2.4 A resolution. Nature 395:347-353

Swayne LA, Chen L, Hameed S, Barr W, Charlesworth E, Colicos MA et al (2005) Crosstalk between huntingtin and syntaxin $1 \mathrm{~A}$ regulates N-type calcium channels. Mol Cell Neurosci 30:339-351

Swayne LA, Beck KE, Braun JE (2006) The cysteine string protein multimeric complex. Biochem Biophys Res Commun 348:83-91

Takahashi M, Seagar MJ, Jones JF, Reber BF, Catterall WA (1987) Subunit structure of dihydropyridine-sensitive calcium channels from skeletal muscle. Proc Natl Acad Sci U S A 84:5478-5482

Tedford HW, Zamponi GW (2006) Direct G protein modulation of $\mathrm{Ca}_{\mathrm{V}} 2$ calcium channels. Pharmacol Rev 58:837-862

Timmermann DB, Westenbroek RE, Schousboe A, Catterall WA (2002) Distribution of highvoltage-activated calcium channels in cultured gamma-aminobutyric acidergic neurons from mouse cerebral cortex. J Neurosci Res 67:48-61 
Toonen RF, Verhage M (2007) Munc18-1 in secretion: lonely Munc joins SNARE team and takes control. Trends Neurosci 30:564-572

Trus M, Wiser O, Goodnough MC, Atlas D (2001) The transmembrane domain of syntaxin 1A negatively regulates voltage-sensitive $\mathrm{Ca}^{2+}$ channels. Neuroscience 104:599-607

Tucker WC, Chapman ER (2002) Role of synaptotagmin in $\mathrm{Ca}^{2+}$-triggered exocytosis. Biochem J 366:1-13

Vendel AC, Terry MD, Striegel AR, Iverson NM, Leuranguer V, Rithner CD et al (2006) Alternative splicing of the voltage-gated $\mathrm{Ca}^{2+}$ channel beta4 subunit creates a uniquely folded $\mathrm{N}$-terminal protein binding domain with cell-specific expression in the cerebellar cortex. J Neurosci 26:2635-2644

Verhage M, Maia AS, Plomp JJ, Brussaard AB, Heeroma JH, Vermeer H et al (2000) Synaptic assembly of the brain in the absence of neurotransmitter secretion. Science 287:864-869

Wadel K, Neher E, Sakaba T (2007) The coupling between synaptic vesicles and $\mathrm{Ca}^{2+}$ channels determines fast neurotransmitter release. Neuron 53:563-575

Wang Y, Sugita S, Sudhof TC (2000) The RIM/NIM family of neuronal C2 domain proteins. Interactions with Rab3 and a new class of Src homology 3 domain proteins. J Biol Chem 275:20033-20044

Weber AM, Wong FK, Tufford AR, Schlichter LC, Matveev V, Stanley EF (2010) N-type Ca ${ }^{2+}$ channels carry the largest current: implications for nanodomains and transmitter release. Nat Neurosci 13:1348-1350

Weiss $N$ (2006) The calcium channel beta4a subunit: a scaffolding protein between voltage-gated calcium channel and presynaptic vesicle-release machinery? J Neurosci 26:6117-6118

Weiss N (2010) Control of depolarization-evoked presynaptic neurotransmitter release by $\mathrm{Ca}_{\mathrm{v}} 2.1$ calcium channel: old story, new insights. Channels (Austin) 4:431-433

Weiss N, Zamponi GW (2012) Control of low-threshold exocytosis by T-type calcium channels. Biochim Biophys Acta 85:131-136

Weiss N, Sandoval A, Kyonaka S, Felix R, Mori Y, De Waard M (2011) Rim1 modulates direct G-protein regulation of $\mathrm{Ca}_{\mathrm{V}} 2.2$ channels. Pflugers Arch 461:447-459

Weiss N, Hameed S, Fernandez-Fernandez JM, Fablet K, Karmazinova M, Poillot C et al (2012) A Ca $3.2 /$ syntaxin-1A signaling complex controls T-type channel activity and low-threshold exocytosis. J Biol Chem 287:2810-2818

Westenbroek RE, Hell JW, Warner C, Dubel SJ, Snutch TP, Catterall WA (1992) Biochemical properties and subcellular distribution of an $\mathrm{N}$-type calcium channel alpha 1 subunit. Neuron 9:1099-1115

Westenbroek RE, Sakurai T, Elliott EM, Hell JW, Starr TV, Snutch TP et al (1995) Immunochemical identification and subcellular distribution of the alpha 1A subunits of brain calcium channels. J Neurosci 15:6403-6418

Westenbroek RE, Hoskins L, Catterall WA (1998) Localization of $\mathrm{Ca}^{2+}$ channel subtypes on rat spinal motor neurons, interneurons, and nerve terminals. J Neurosci 18:6319-6330

Wheeler DB, Randall A, Tsien RW (1994) Roles of N-type and Q-type $\mathrm{Ca}^{2+}$ channels in supporting hippocampal synaptic transmission. Science 264:107-111

Wiser O, Bennett MK, Atlas D (1996) Functional interaction of syntaxin and SNAP-25 with voltage-sensitive $\mathrm{L}$ - and $\mathrm{N}$-type $\mathrm{Ca}^{2+}$ channels. Embo J 15:4100-4110

Wiser O, Cohen R, Atlas D (2002) Ionic dependence of $\mathrm{Ca}^{2+}$ channel modulation by syntaxin 1A. Proc Natl Acad Sci U S A 99:3968-3973

Wong FK, Stanley EF (2010) Rab3a interacting molecule (RIM) and the tethering of pre-synaptic transmitter release site-associated $\mathrm{Ca}_{\mathrm{v}} 2.2$ calcium channels. J Neurochem 112:463-473

Wu LG, Borst JG, Sakmann B (1998) R-type $\mathrm{Ca}^{2+}$ currents evoke transmitter release at a rat central synapse. Proc Natl Acad Sci U S A 95:4720-4725

Wu MN, Fergestad T, Lloyd TE, He Y, Broadie K, Bellen HJ (1999) Syntaxin 1A interacts with multiple exocytic proteins to regulate neurotransmitter release in vivo. Neuron 23:593-605

Xu J, Mashimo T, Sudhof TC (2007) Synaptotagmin-1, -2, and -9: $\mathrm{Ca}^{2+}$ sensors for fast release that specify distinct presynaptic properties in subsets of neurons. Neuron 54:567-581 
Yokoyama CT, Sheng ZH, Catterall WA (1997) Phosphorylation of the synaptic protein interaction site on N-type calcium channels inhibits interactions with SNARE proteins. J Neurosci 17:6929-6938

Yokoyama CT, Myers SJ, Fu J, Mockus SM, Scheuer T, Catterall WA (2005) Mechanism of SNARE protein binding and regulation of $\mathrm{Ca}_{\mathrm{V}} 2$ channels by phosphorylation of the synaptic protein interaction site. Mol Cell Neurosci 28:1-17

Yoon EJ, Gerachshenko T, Spiegelberg BD, Alford S, Hamm HE (2007) Gbetagamma interferes with $\mathrm{Ca}^{2+}$-dependent binding of synaptotagmin to the soluble $\mathrm{N}$-ethylmaleimide-sensitive factor attachment protein receptor (SNARE) complex. Mol Pharmacol 72:1210-1219

Yoshida A, Oho C, Omori A, Kuwahara R, Ito T, Takahashi M (1992) HPC-1 is associated with synaptotagmin and omega-conotoxin receptor. J Biol Chem 267:24925-24928

Zamponi GW, Bourinet E, Nelson D, Nargeot J, Snutch TP (1997) Crosstalk between G proteins and protein kinase $C$ mediated by the calcium channel alpha1 subunit. Nature 385:442-446

Zhong H, Yokoyama CT, Scheuer T, Catterall WA (1999) Reciprocal regulation of P/Q-type Ca ${ }^{2+}$ channels by SNAP-25, syntaxin and synaptotagmin. Nat Neurosci 2:939-941

Zhu LQ, Liu D, Hu J, Cheng J, Wang SH, Wang Q et al (2010) GSK-3 beta inhibits presynaptic vesicle exocytosis by phosphorylating P/Q-type calcium channel and interrupting SNARE complex formation. J Neurosci 30:3624-3633 